\title{
An Experimental and Numerical Study of Landslides Triggered by Agricultural Irrigation in Northwestern China
}

\author{
Tianfeng Gu $\mathbb{D},{ }^{1}$ Pingping Sun $\mathbb{D}^{2},{ }^{2}$ Jiading Wang $\mathbb{D}^{1},{ }^{1}$ Herry Lin, ${ }^{3}$ Yuanjun Xu $\mathbb{D}^{1}$, \\ Jiaxu Kong $\mathbb{D}^{1}$, and Bin Sun $\mathbb{D}^{1}$ \\ ${ }^{1}$ State Key Laboratory of Continental Dynamics/Department of Geology, Northwest University, Xi'an, Shaanxi 710069, China \\ ${ }^{2}$ Xi'an Center of Geological Survey, China Geological Survey, Xi'an, Shaanxi 710054, China \\ ${ }^{3}$ Department of Ecosystem Science and Management, The Pennsylvania State University, University Park, PA 16802, USA
}

Correspondence should be addressed to Jiading Wang; wangjiading029@163.com

Received 6 August 2020; Revised 17 October 2020; Accepted 3 November 2020; Published 1 December 2020

Academic Editor: Chong Xu

Copyright $\odot 2020$ Tianfeng Gu et al. This is an open access article distributed under the Creative Commons Attribution License, which permits unrestricted use, distribution, and reproduction in any medium, provided the original work is properly cited.

Chinese Loess Plateau (CLP) has become one of the high-incidence areas of landslide disasters in China, especially at the edge of the tablelands where irrigation has been practiced at a large scale since the 1960s. Heifangtai tableland, located in the CLP in Yongjing County, Gansu Province, has been selected as a case, where more than 90 slidings occurred in the past three decades. Field monitoring and laboratory tests were conducted to obtain the soil-water characteristic curve, unsaturated soil shear strength, irrigation water infiltration, and the groundwater level change. Based on these results, a three-dimensional numerical model of the slope was established, and the change of seepage field and slope stability before and after irrigation was investigated using simulations and compared with the observed data. The results show that flood irrigation raised the water table, and the increase of soil moisture in the flooded area was more significant than that in the nonirrigated area. The rising speed of the groundwater level was about $0.25 \mathrm{~m} / \mathrm{yr}$, with an amplitude of $0.5 \mathrm{~m}$. Near the slope, the hydraulic gradient of the concave slope was steeper than the convex slope. The shear strength of the loess decreased with increasing soil moisture, and the tensile strength was about $15 \%$ of the cohesion. Numerical results showed that after three years of continuous flood irrigation at the back of the slope, the slope stability coefficient decreased by 0.12 . After irrigation, the potential slip zone slightly expanded. The reason why landslides often occurred at the back of the gully or the landslide was that the water table was shallower on concave slopes and the soil moisture of the concave slopes was more susceptible to irrigation.

\section{Introduction}

The Chinese Loess Plateau (CLP) is an agricultural region. Because of its semihumid to arid climate with intense evaporation, irrigation has become an essential way of ensuring agricultural productivity in this region. However, landslides frequently occur on the edge of the loess tablelands, which features group-occurrence and reoccurrence of landslides [1-9]. Therefore, the edges of these tablelands have become one of the most vulnerable areas for geological disasters in western China [10-12]. The root cause of loess landslides induced by irrigation is that the original hydrogeological and hydropedological conditions have been significantly altered. The mechanism of irrigation infiltration thus becomes the basis for understanding the mechanisms leading to this kind of landslide.

In recent years, the process of irrigation infiltration has been studied through field investigation, laboratory experiments, and numerical analysis [13-16]. Some new mechanisms of the irrigation-induced landslide have been reported, such as static liquefaction $[4,17]$, frozen stagnant water $[18,19]$, and irrigating effect $[20,21]$, which have advanced the understanding of mechanisms of the irrigation-induced landslides. However, there have been a few studies on the seepage field of slopes at the edges of the loess tablelands, but the distribution and variation of the slope seepage field were recently recognized as the main factors contributing to the development of landslides. On-site 
hydropedological observations are the most effective way to reveal the underlying mechanisms.

Irrigation can not only change the groundwater levels but the physical properties of the loess. Many scholars [22-31] have studied the physical and mechanical properties of loess under irrigation. They obtained the soil-water characteristic curves and permeability properties of loess under different conditions, as well as the deformation and strength characteristics of loess under different stress paths. These findings revealed the changes in loess properties caused by irrigation from various perspectives. However, these studies overlooked the tensile strength of loess. As the soil in the back margin of a loess landslide is tension failure, it is necessary to take into account the tensile strength of loess with stability analysis.

In general, the slope stability analysis and the shear strength of saturated soils are adopted as the parameter of slip zone below the groundwater level, whereas the shear strength from the undisturbed soil or plastic limit soil is adopted as the parameter of the rest slip zone [7, 32]. This method is not reasonable to loess landslides induced by irrigation because, for such landslides, most of the slip zones are above the groundwater level. Therefore, the distribution of the matric suction and the shear strength of unsaturated soils should be considered. On the other hand, landslides, soil erosion, and fluvial erosion result in shattered tableland edge, implying that the slopes are different in shape. Therefore, local topography should be considered in the stability analysis as well. In recent years, the mechanism of water-induced loess landslides from the perspective of unsaturated soil mechanics has received heightened attention [33-35]. However, existing studies have mainly focused on two-dimensional stability analysis. Thus, it is necessary to study the mechanism of slope instability from unsaturated soil principles and three-dimensional slope stability analysis.

In the present study, field monitoring and laboratory tests were conducted to obtain soil-water characteristic curve (SWCC), unsaturated shear strength, infiltration process of rainfall and irrigation water, and groundwater level change. Based on these, we established a three-dimensional numerical analysis model of slope and simulated the change of seepage field during irrigation. Slope stability before and after irrigation was calculated, and the effect of irrigation on seepage field and slope stability was investigated and compared with actual observations.

\section{Materials and Methods}

2.1. Landslide Details. The Heifangtai tableland is in Yanguoxia, Yongjing County, Gansu Province, located on the north bank of the Yellow River (Figure 1(a)). It includes Fangtai tableland in the west with an area of $1.5 \mathrm{~km}^{2}$ and Heitai tableland in the east with an area of $9 \mathrm{~km}^{2}$ (Figure 1(b)). The groundwater level has risen by over $20 \mathrm{~m}$ since flood irrigation was introduced in 1968 [36]. More than 90 slidings have occurred in the past three decades (Figure 2(a)), with an average of 3-5 landslides per year $[5,9,19,26,33]$. It usually happens in March and July (Figure 2(b)). Luojiapo section in the north of Dangchuan village is one of the areas where landslides have concentrated in recent years. The length of the tableland edge is about $1.2 \mathrm{~km}$, with more than ten landslides occurring from the 1990s to 2010s (Figure 1(c)). On April 29 ${ }^{\text {th }}, 2015$, a landslide occurred at the Luojiapo (Figure 3 ). The sliding could be divided into two stages [37]. In the first stage, the sliding body was about $20 \mathrm{~m}$ long and $115 \mathrm{~m}$ wide and covered an area of approximately $8 \times 103 \mathrm{~m}^{2}$. What is more, the volume of the sliding body was $2.5 \times 105 \mathrm{~m}^{3}$ and the sliding distance is $437 \mathrm{~m}$ (Zone I of Figure 3(d)). In the second stage, about 3 hours after the first sliding, the main scarp of the landslide retreated $130 \mathrm{~m}$, with an area of $2.7 \times 10^{4} \mathrm{~m}^{2}$, a volume of $3.2 \times 10^{5} \mathrm{~m}^{3}$, and a sliding distance of $782 \mathrm{~m}$ (Zone II of Figure $3(\mathrm{~d})$ ). The landslide destroyed 14 households and 3 factories as well as the farmland downstream of it. About $100 \mathrm{~m}$ away, another landslide occurred on February $19^{\text {th }}$, 2017 (Figure 1(c)), which destroyed some farmers' greenhouses, farmland, and the diversion canal. The maximum width of the landslide was $178 \mathrm{~m}$, and the total area was $5.81 \times 10^{4} \mathrm{~m}^{2}$.

The top elevation of the landslide is $1710 \mathrm{~m}$, and the bottom elevation is $1600 \mathrm{~m}$, with a relative elevation difference of $110 \mathrm{~m}$ (Figures 3(d) and 3(e)). The stratigraphic column comprises Holocene Series slide sediment layer $\left(\mathrm{Q}_{4}{ }^{\mathrm{del}}\right)$, Quaternary Pleistocene loess $\left(\mathrm{Q}_{\mathrm{p}}{ }^{3 \mathrm{eol}}\right)$, Middle Pleistocene alluvial sediment $\left(\mathrm{Q}_{\mathrm{p}}{ }^{2 \mathrm{al}}\right)$, and Lower Cretaceous Hekou Group $\left(\mathrm{K}_{1}{ }^{\mathrm{hk}}\right)$. The Holocene Series slide sediment layer $\left(\mathrm{Q}_{4}{ }^{\mathrm{del}}\right)$ consists of loess, gravel, and sandy mudstone after sliding accumulated in the middle and lower part of the slope. The $30 \mathrm{~m}$ thick Quaternary Pleistocene loess $\left(\mathrm{Q}_{\mathrm{p}}{ }^{3 e \mathrm{l}}\right)$ is grey-yellow, mainly silt, homogeneous, and porous. For Middle Pleistocene alluvial sediment $\left(\mathrm{Q}_{\mathrm{p}}{ }^{2 \mathrm{al}}\right)$, the upper is maroon, 3-5 m thick silty clay, whereas the lower is sand gravel and pebbles with a thickness of 2-3 $\mathrm{m}$. The Lower Cretaceous Estuary Group $\left(K_{1}{ }^{h k}\right)$ is a purple-dark red mudstone and sandy mudstone.

2.2. Basic Mechanical Test of Soil. Basic soil physical properties, soil-water characteristic curve (SWCC), hydraulic conductivity function (HCF), and strength characteristics (shear strength and tensile strength) of the loess were tested in the laboratory. The undisturbed loess samples were collected in a test well, with a size of $0.3 \mathrm{~m} \times 0.3 \mathrm{~m} \times 0.3 \mathrm{~m}$. The soil's physical properties were measured according to the China soil test standards (GB/T 50123-1999), as listed in Table 1.

The soil-water characteristic test was carried out by TRIM (Transient Release and Imbibition Method), which provides a fast, accurate, and simple testing for obtaining SWCC and HCF of various types of soils under both wetting and drying states [38, 39]. TRIM employs the simple and reliable measurement of transient water content by electronic balance to record the signature of transient unsaturated flow in the soil sample, and it takes advantage of the robust inverse modeling capability to simulate the seepage process [39].

The unsaturated triaxial apparatus (FLSY-30) was utilized in the triaxial shear test, which is used to perform the 

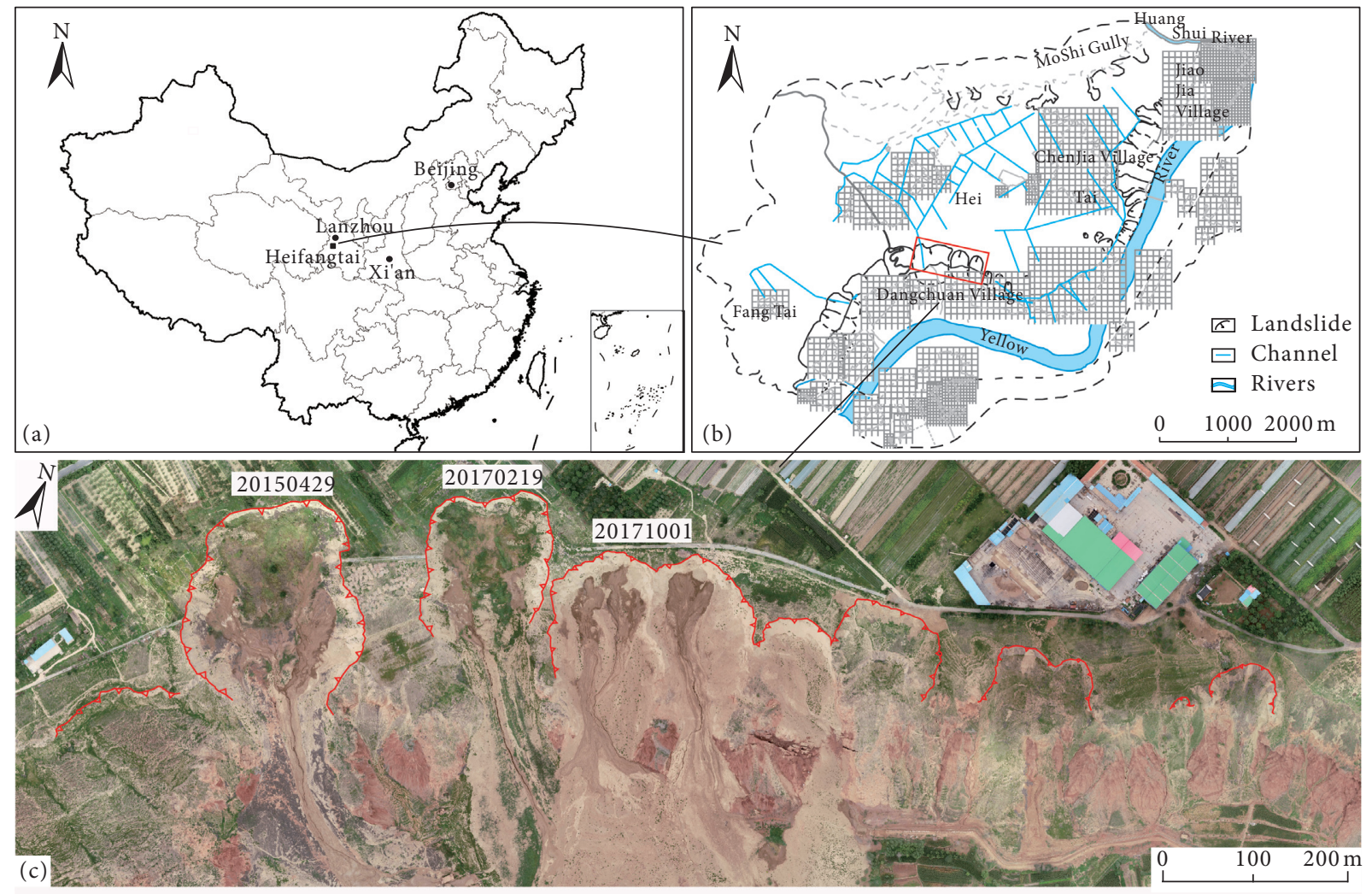

Figure 1: (a) Location of the study area. (b) Channels and landslides distribution map in the study area. (c) UAV orthoimage (DOM) of the study area (obtained in August 2018) showing several landslide areas marked by the date of occurrence (year-month-day).

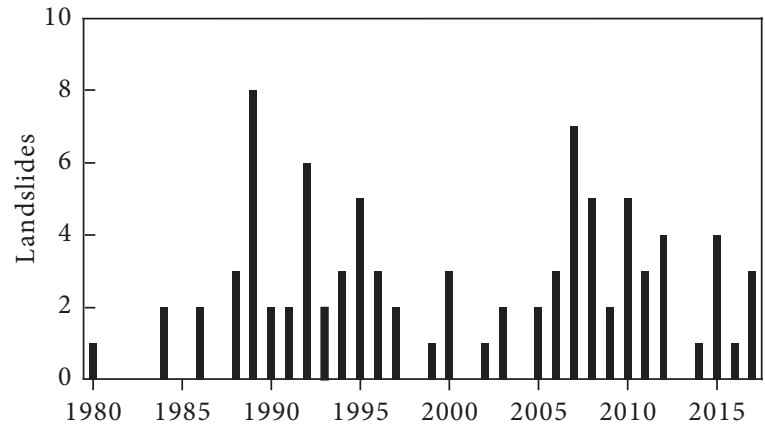

(a)

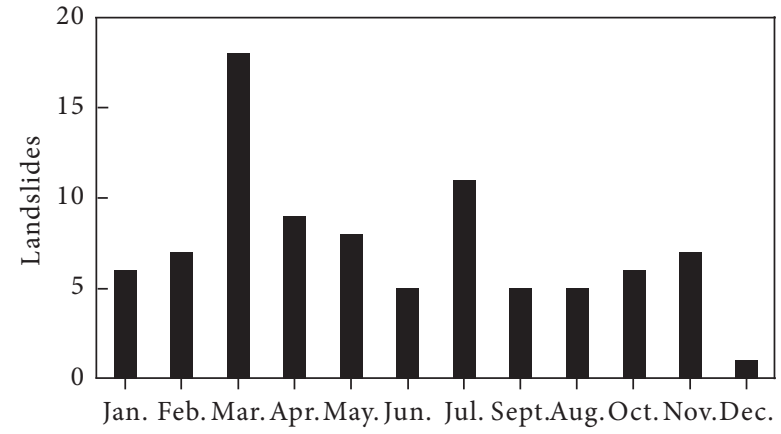

(b)

FIgUre 2: Frequency distribution of landslides in the study area. (a) Annual number of landslides from 1980 to 2017 . (b) Monthly total landslides from 1980 to 2017.

test under unsaturated condition by adopting the axis translation technique to control both pore water and air pressure to maintain matric suction within the specimen. The tests were conducted under different matric suctions $(0$, $30,50,100$, and $200 \mathrm{kPa}$ ) and different net confining pressures $(100,200$, and $300 \mathrm{kPa})$. The shear rate was $0.01 \mathrm{~mm} / \mathrm{min}$. The test samples are $38 \mathrm{~mm}$ in height and $76 \mathrm{~mm}$ in diameter.

A horizontal geotechnical tension tester made by ourselves was used for the tensile strength test, which is composed of a stepping motor-controlled tension frame and a data acquisition controller. To study the effect of soil moisture content on tensile strength, we designed several groups of tests with different soil moisture contents $(3 \%, 6 \%$, $9 \%, 12 \%, 15 \%$, and $20 \%$ by weight), which were adjusted by water injection or air drying. The undisturbed loess sample was cut into cylindrical with a length of $100 \mathrm{~mm}$ and a diameter of $40 \mathrm{~mm}$. Through the above test, we get the test results of Figure 4.

2.3. Field Monitoring. To study the effect of irrigation on groundwater level and seepage field, we selected two representative monitoring sections (Figure 5) at the west part of 

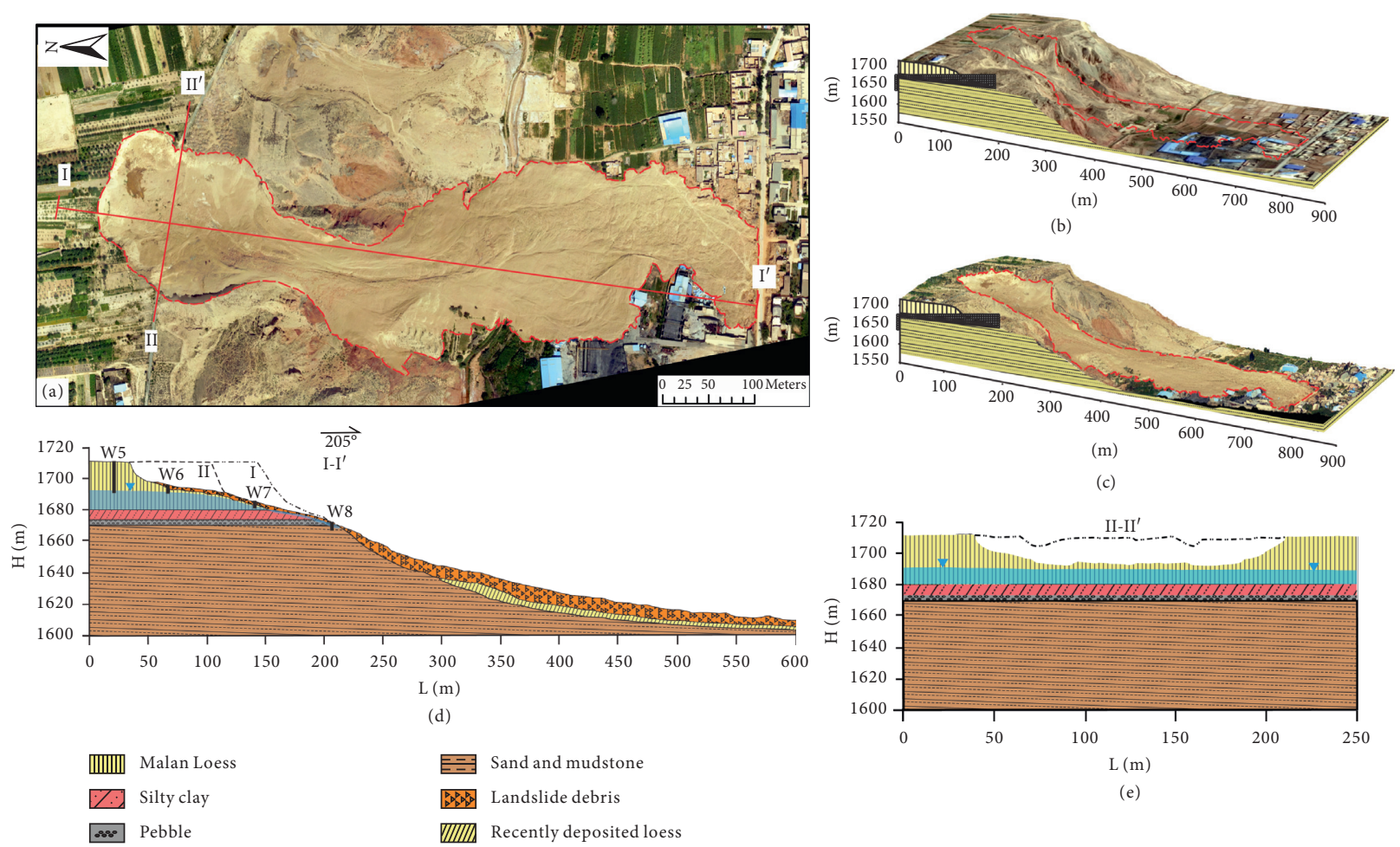

(e)

Figure 3: Landslide of Luojiapo occurred on April 29, 2015: (a) UAV orthoimage (2015.7) with the transects (I-I' and II-II') highlighted by red lines shown on the right side (b and c); (b) 3D map before sliding (2015.3); (c) 3D map after sliding (2015.7); (d) engineering geological profile of transect (I-I'); and (e) engineering geological profile of transect II-II'.

TABLE 1: Basic parameters of the four layers investigated.

\begin{tabular}{lcccc}
\hline Wet density $\rho\left(\mathrm{g} / \mathrm{cm}^{3}\right)$ & Moisture content $w(\%)$ & Proportion $G_{\mathrm{s}}$ & Plastic limit $w_{p}(\%)$ & Liquid limit $w_{1}(\%)$ \\
\hline $1.46 \sim 1.49$ & $4.5 \sim 5.9$ & 2.69 & $16.26 \sim 18.69$ & $27.67 \sim 28.56$ \\
\hline
\end{tabular}

Dangchuan landslides in 2015. The effects of slope type (convex and concave) on seepage were monitored. One section was set on a convex slope with soil moisture, pore pressure, and ground temperature sensors (Figure 5). Soil moisture sensors (accuracy $\pm 2 \%$ ) were installed in farmland with depths of $0.1,0.2,0.5,1,1.5,2,3$, and $5 \mathrm{~m}$, respectively. Four pore pressure sensors (accuracy $0.1 \%$ ) were buried along the profile from north to south. The W1 was in the same location as the soil moisture monitoring site. The W2 was outside the farmland, W3 was at the edge of the slope, and W4 was at the groundwater outlet under the slope (Figure 5). Two sets of temperature sensors (accuracy 0.1\%) were installed on the tableland and at the outlet of the slope, respectively, at depths of $0.2,0.3,0.4,0.6,0.8$, and $1 \mathrm{~m}$. The second monitoring section was set at the back of the landslide (Figure 5). Four pore pressure sensors were buried from north to south.

\subsection{Numerical Analysis}

2.4.1. Seepage Analysis. At the same time, through the use of Midas software combined with the finite-element method (fem), Midas is a finite-element analysis software, which can be divided into four categories: construction, bridge, geotechnical, and simulation. In the geotechnical field, not only does it support linear nonlinear static analysis, linear nonlinear dynamic analysis, seepage and consolidation analysis, slope stability analysis, construction stage analysis, and other analysis types, but also it can carry out seepage stress coupling, stress slope coupling, seepage slope coupling, nonlinear dynamic analysis slope coupling, and so on. It is widely used for accurate modeling and analysis of subway, tunnel, slope, foundation pit, and various practical projects. A finite-element model (Figure 6) was built for saturated-unsaturated seepage analysis, according to the terrain before the landslides occurred. Because the fluctuation of the loess table is very small, the horizontal uneven soil layer is simplified to a fixed dip angle in the construction of the three-dimensional mold. The rest of the formation parameters are obtained by geological drilling, and the physical and mechanical parameters of rock and soil mass are obtained by laboratory tests. The model was $72 \mathrm{~m}$ in height, $200 \mathrm{~m}$ in width, and $223 \mathrm{~m}$ in length, with horizontal constraints on both sides, horizontal and vertical restraints at the bottom. There are 96,824 cells and 60,000 nodes in the model. Since 2012, the process of loess irrigation and infiltration was very slow, and the response between irrigation events and groundwater level was about 8-10 months. Numerical analysis should be carried out on a longer time 


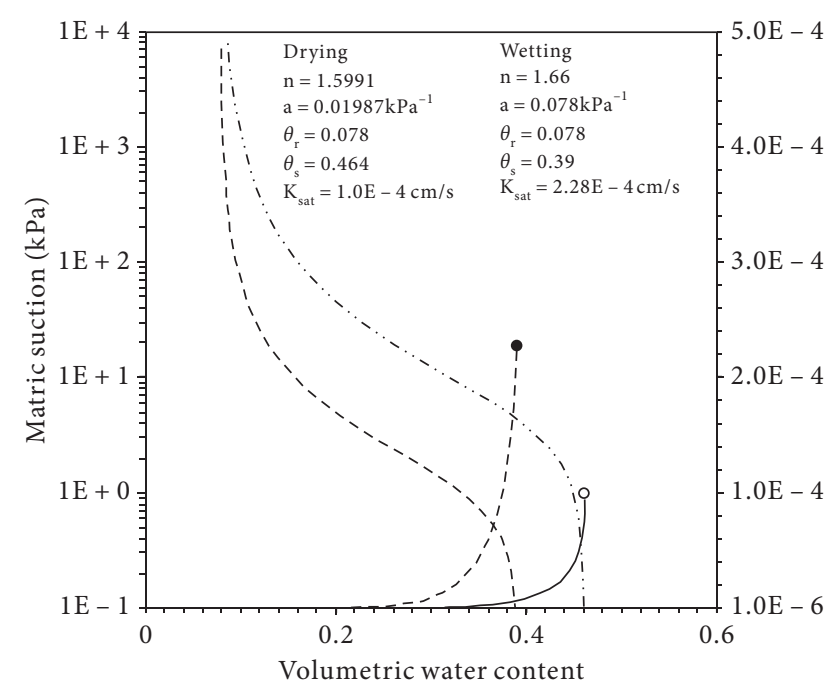

(a)

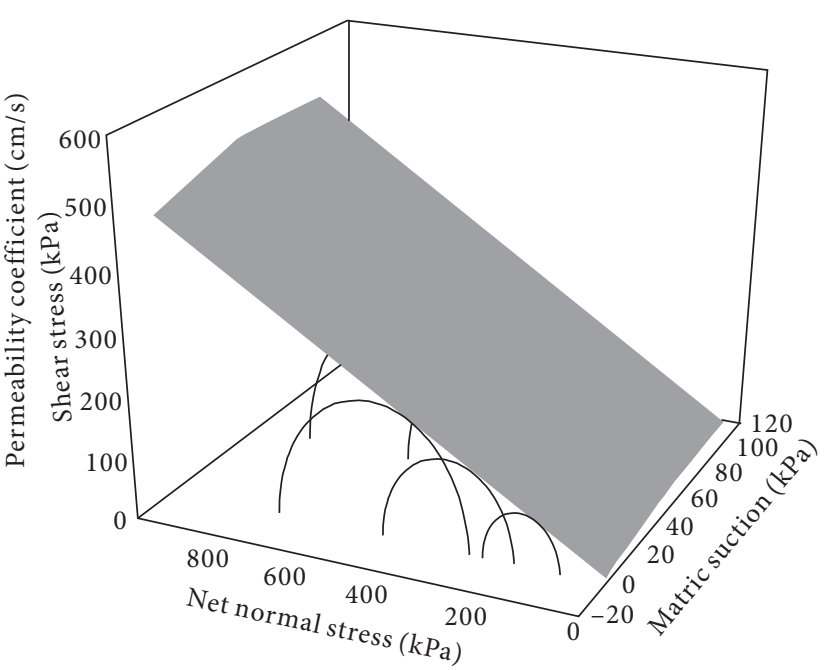

(b)

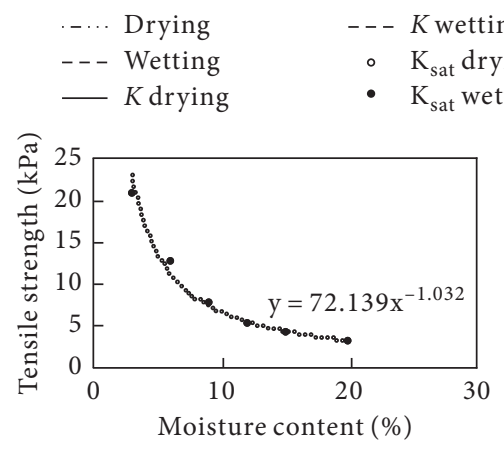

(c)

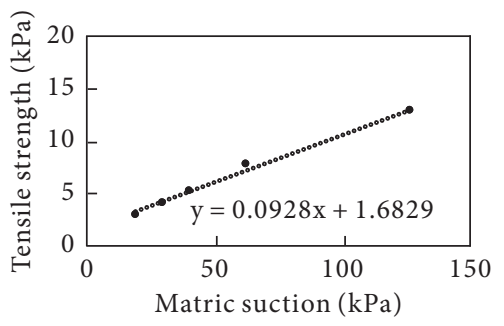

(d)

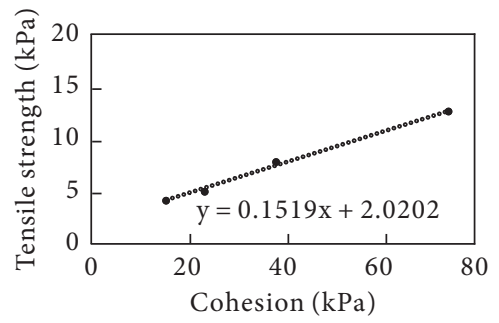

(e)

FIGURE 4: Laboratory test results of Malan Loess from Heifangtai. (a) The soil-water characteristic curve (SWCC) and hydraulic conductivity function (HCF) curve for both wetting and drying based on TRIM test. (b) Extended Mohr-Coulomb failure enveloping surface based on unsaturated soil triaxial test. (c) Tensile strength versus moisture content curve based on the tensile test. (d) Tensile strength versus loess matric suction curve based on tensile test and SWCC. (e) Tensile strength versus cohesion curve based on tensile test and unsaturated soil triaxial test.

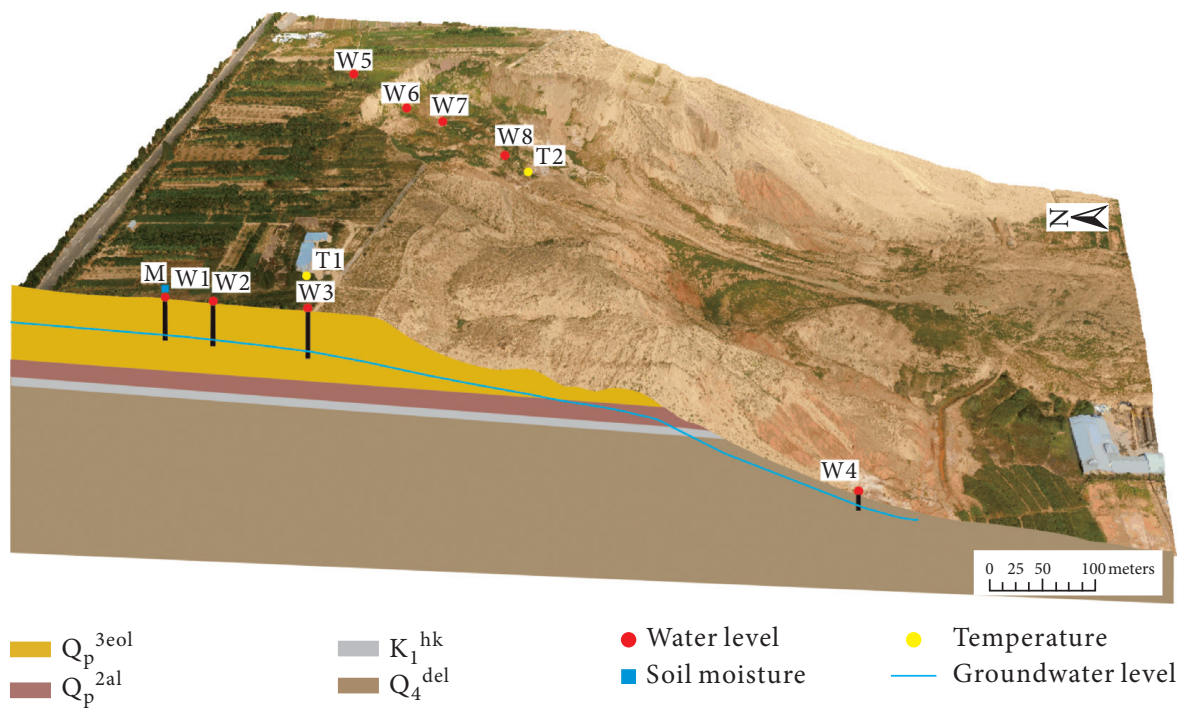

FIgURE 5: Site monitoring layout in Luojiapo: $\mathrm{T} 1$ and $\mathrm{T} 2$ are ground temperature monitoring points, $\mathrm{M}$ is soil moisture monitoring points, and $\mathrm{W} 1$ to $\mathrm{W} 8$ are underground water level monitoring points. 


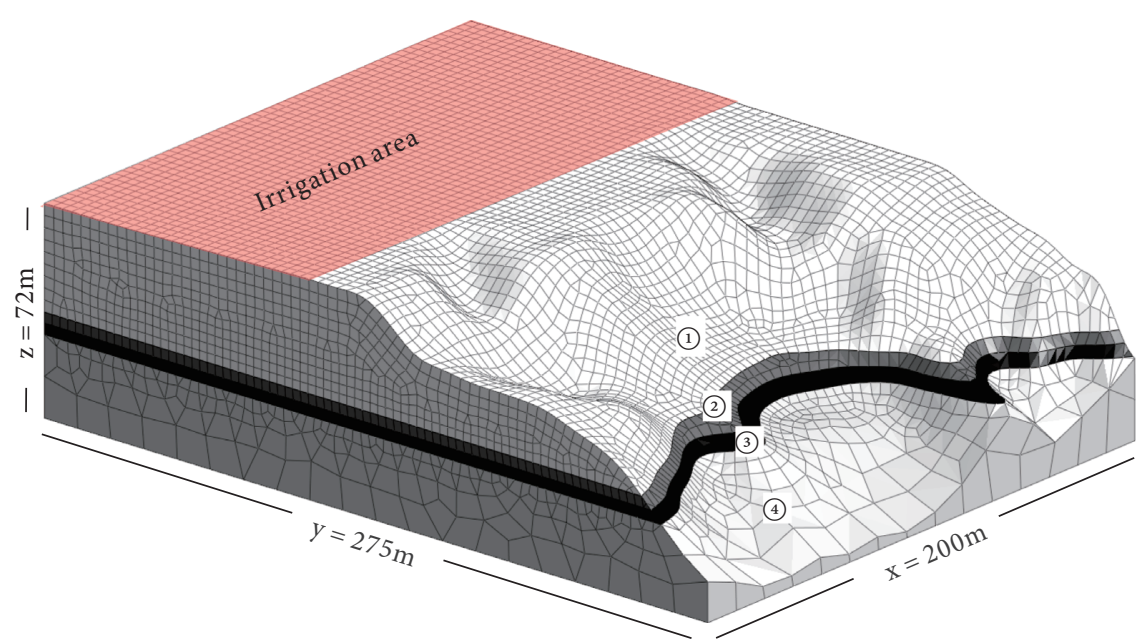

Figure 6: Numerical model grid layout. (1) Loess. (2) Silty clay. (3) Sand pebble layer. (4) Interbedded sand mudstone (see Figure 4 as a reference)).

scale, but $3 \mathrm{D}$ calculation requires a large amount of calculation. In addition, the 2015 landslide occurred on this slope. Based on comprehensive consideration, 2012 was selected as the initial stage in this paper, and the analysis duration was set as three years to simulate the impact of irrigation on the slope seepage field. On the left side of the model, the variable head boundary was set, and the groundwater level in 2012 was taken as the benchmark (the initial stable water level was 18.0 meters), with an annual increase of $0.27 \mathrm{~m}$ to simulate the rise of the groundwater level. Irrigation subarea was set on the top with a width of $200 \mathrm{~m}$ and a length of $100 \mathrm{~m}$, with the pressure head set at $0.05 \mathrm{~m}$ when irrigated and $0 \mathrm{~m}$ with no irrigation, to simulate the effect of flood irrigation. The bottom was set as an impervious boundary, and the slope was set as a seepage surface boundary. We modeled the irrigation process as flood irrigation that started once every two months, with each carried out for 5 days.

Soil-water characteristic function and soil permeability coefficient function was required for saturatedunsaturated seepage analysis. The mechanical behavior and hydraulic characteristics of the unsaturated soils are closely related to the soil-water characteristic curve $[40,41]$. The soil-water characteristic test of the loess was carried out by TRIM (Figure 4(a)). Other parameters were determined according to the results of the laboratory test and pumping test [36].

2.4.2. Slope Stability Analysis. The two-dimensional analysis program has been widely used because of its simplicity in the calculation, but the landslide is a three-dimensional mass movement, especially the loess landslide induced by irrigation. The occurrence of landslides is often related to the microtopography of the slope. The three-dimensional stability analysis can reflect the actual state of the landslide and obtain more realistic analysis results. Therefore, we adopted a three-dimensional slope stability analysis.

In this study, the 3D analysis was conducted for unsaturated slope stability. We conducted the unsaturated stability function analysis by the built-in language of FISH in FLAC3D [33]. The shear strength and the tensile strength of unsaturated loess are shown in Section 3.1.2 respectively. Other parameters are shown in Table 2.

The results of seepage analysis are mainly applied in two aspects. On the one hand, the influence of irrigation on the internal pore pressure and underground water level of the slope is analyzed, mainly including the pore pressure and water level at different positions (the protruding part and the sag part). Close to the irrigation area, the water content increases and the negative pore pressure decreases (matric suction). On the other hand, soil shear strength parameters can be calculated by pore pressure; if $u_{w}<0$, the zone is unsaturated and the matric suction is $u_{a}-u_{w}$. So, the soil cohesion of the zone can be set to $c^{\prime}+\left(u_{a}-u_{w}\right) \tan \varphi^{b}$, where $c^{\prime}=$ effective cohesion, $u_{a}=$ pore air pressure, $u_{w}=$ pore water pressure, and $\varphi^{b}=$ internal friction angle corresponding to the matric suction, which represents the slope that the shear strength increases with the matric suction. If $u_{w} \geq 0$, the soil is saturated. In this way, the relationship between matric suction and strength is implemented. Finally, the safety factor is calculated by strength reduction methods.

\section{Results}

3.1. Loess Mechanical Properties. Based on the Hydrus-1D program, the data acquired by the TRIM test under wetting and drying states were fitted by using the van Genuchten model to gain the SWCC and HCF [39] (Figure 4(a)).

3.1.1. Unsaturated Shear Strength. The expanded Mohr-Coulomb failure surface of the unsaturated soils (Figure 4(b)) was plotted based on the triaxial test of unsaturated soils [42]. It is shown that the Mohr-Coulomb failure enveloping surface was a curved surface. The shearing strength of unsaturated loess could be obtained, according to Fredlund's two stress variable formula: 
TABLE 2: Basic parameters of the four layers investigated.

\begin{tabular}{|c|c|c|c|c|c|c|c|c|}
\hline $\begin{array}{l}\text { Lithology } \\
\text { name }\end{array}$ & $\begin{array}{l}\text { Rock and soil } \\
\text { layer depth } \\
\text { (m) }\end{array}$ & $\begin{array}{c}\text { Density } \rho \\
\left(\mathrm{kN} / \mathrm{m}^{3}\right)\end{array}$ & $\begin{array}{l}\text { The angle of } \\
\text { internal } \\
\text { friction }\left({ }^{\circ}\right)\end{array}$ & $\begin{array}{c}\text { Cohesive } \\
\text { forces }(\mathrm{kPa})\end{array}$ & $\begin{array}{c}\text { Elastic } \\
\text { modulus } E \\
(\mathrm{MPa})\end{array}$ & $\begin{array}{l}\text { Poisson's } \\
\text { ratio } \mu\end{array}$ & $\begin{array}{c}\text { Porosity } \\
n\end{array}$ & $\begin{array}{c}\text { Saturated } \\
\text { permeability } \\
\text { coefficient } K_{\text {sat }}(\mathrm{m} / \mathrm{d})\end{array}$ \\
\hline Loess & 49.0 & 15.2 & 23.6 & 24.0 & 46 & 0.35 & 0.49 & $2.1 e-1$ \\
\hline Silty clay & 2.2 & 1.95 & 22.0 & 80.0 & 90 & 0.3 & 0.30 & $2 e-4$ \\
\hline $\begin{array}{l}\text { Sand pebble } \\
\text { layer }\end{array}$ & 34 & 20.0 & 28.0 & 3.0 & 140 & 0.3 & 0.40 & 2.0 \\
\hline $\begin{array}{l}\text { Sand } \\
\text { mudstone }\end{array}$ & 67.0 & 2.0 & 43.0 & 15.0 & 200 & 0.3 & 0.10 & $1 \underline{e}-5$ \\
\hline
\end{tabular}

$$
\tau_{f}=c^{\prime}+\left(\sigma-u_{a}\right)_{f} \tan \varphi^{\prime}+\left(u_{a}-u_{w}\right)_{f} \tan \varphi^{b},
$$

where $\sigma$ is the direct stress $(\mathrm{Pa}),\left(\sigma-u_{a}\right)_{f}$ is normal stress on the failure surface, and $\left(u_{a}-u_{w}\right)_{f}$ is the matric suction at failure, while the effective cohesion $c^{\prime}$, effective internal friction angle $\varphi^{\prime}$, and suction friction angle $\varphi^{b}$ of the unsaturated loess were $16.9 \mathrm{kPa}, 23.1^{\circ}$, and $15.97^{\circ}$, respectively.

3.1.2. Tensile Strength. The tensile failure surface of the sample is located near the middle of the sample, about $1 / 2$ of the whole test soil sample. The failure surface occurs along the principal stress surface. The fracture cross section is extremely rough and jagged, and the principal stress surface is perpendicular to the tensile axis. The specimen showed brittle failure, and no visible necking phenomenon occurred during the whole tensile process. The curve of tensile strength and soil moisture content (Figure 4(c)) shows that the tensile strength decreased with increasing soil moisture, and its regression was a power function. The curve of tensile strength and matric suction (Figure $4(\mathrm{~d})$ ) was obtained by merging with Figure 4(a). It can be seen that the tensile strength of the loess increased linearly with the matric suction, which was about $10 \%$ of the matric suction. The curve of cohesion and tensile strength (Figure 4(e)) was illustrated by importing the test results in Section 3.1.1. It can be seen that the regression of cohesion and tensile strength was linear, and the tensile strength was about $15 \%$ of the cohesion.

\subsection{Monitoring Results}

3.2.1. Soil Moisture Content. The average annual precipitation of the study area is $287.6 \mathrm{~mm}$ concentrated in July-September, and the average annual evaporation is $1593.4 \mathrm{~mm}$. Since the 1970s, irrigation has been opened in this region five times a year, including spring irrigation (March-May), winter irrigation (November-December), and three times of seedling irrigation. In recent years, the flooding irrigation rose to seven times a year with an annual irrigation quota of $8385 \mathrm{~m}^{3}$ per hectare, for the crops that have been replaced by fruit trees that demand more watering [43].

The soil moisture content at 0.1 and $0.2 \mathrm{~m}$ increased immediately at irrigation (Figure $7(\mathrm{a})$ ). The soil moisture content at $0.5-3 \mathrm{~m}$ increased slowly, and the response time was inversely proportional to depth. The water content at
$5 \mathrm{~m}$ remained unchanged. With the increasing depth, the response time of the change of soil moisture content increases gradually, and the lag effect becomes apparent. Therefore, the thicker the distance from the surface is, the longer the response time of the change in soil moisture content, and the slower the moisture content rising speed is when soil moisture increases.

3.2.2. Groundwater Level. Since 1968, the groundwater level in Heifangtai has risen by an average of $0.27 \mathrm{~m} / \mathrm{yr}$, and, by 2012, the groundwater level has risen by about $20 \mathrm{~m}$ $[12,34,44]$. Groundwater flowed from west to east and is discharged outward from the tableland margin [36]. The groundwater table and its change at the slope had a significant influence on slope stability, so the groundwater table monitoring is essential.

Figure 7(b) shows the monitoring results of the groundwater level from November 2016 to December 2018. The water level of the two monitoring points showed a gradual but cyclical upward trend. Groundwater rose to a relatively high level in March 2017, a relatively low level in August, and then continued to rise, reaching its highest in April 2018. After that, it slowly declined to a low level at the end of July and then rose again. The fluctuation period of the groundwater level was 1 year. The amplitude of W1 was about $0.6 \mathrm{~m}$ and that of W5 was approximately $0.5 \mathrm{~m}$. The rising speed of the water level was about $0.25 \mathrm{~m} / \mathrm{yr}$ of $\mathrm{W} 1$ and $0.22 \mathrm{~m} / \mathrm{yr}$ of W5.

The results show that the groundwater level was different in different locations (Figure $7(\mathrm{c})$ ). The nearer to the center of the tableland, the shallower the groundwater table. Near the slope, the hydraulic gradient of the concave slope was steeper than the convex slope. On the slope, the water level of the concave slope was shallower than that of the convex slope.

3.3. Seepage Analysis. Figure 8 shows the pore pressure distribution of the loess layer before and after irrigation. In the three-dimensional pore pressure images, three longitudinal sections " $a$," "b," and "c" and three transverse sections " $d$," "e," and " $f$ " were cut at a specified interval. The "a" and " $c$ " crossed the concave slope, and " $b$ " crossed the convex slope to obtain the variation of pore pressure at different locations.

From Figure 8(a), the maximum negative pore pressure appeared at the edge of the slope before irrigation. On the 


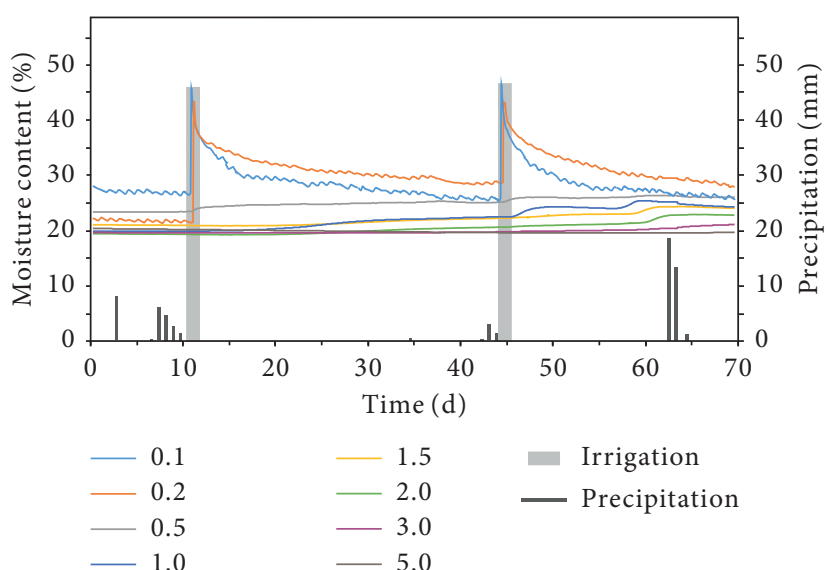

(a)

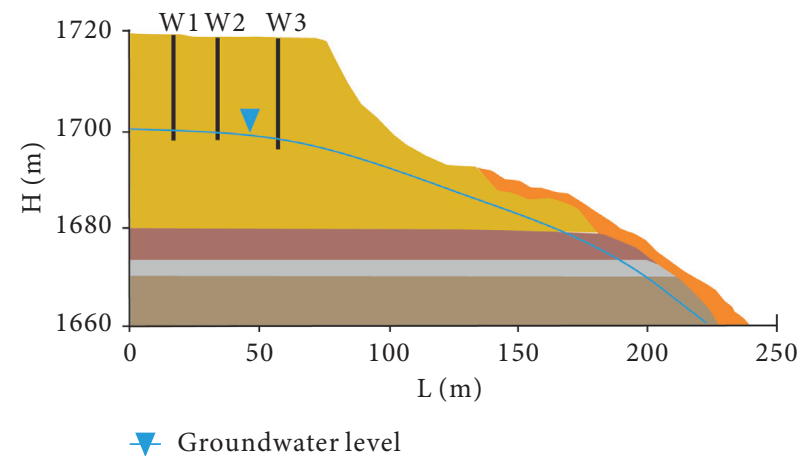

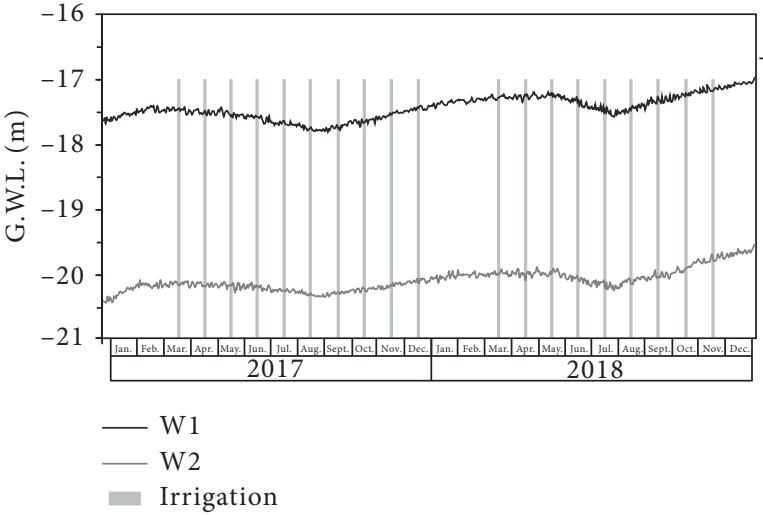

(b)

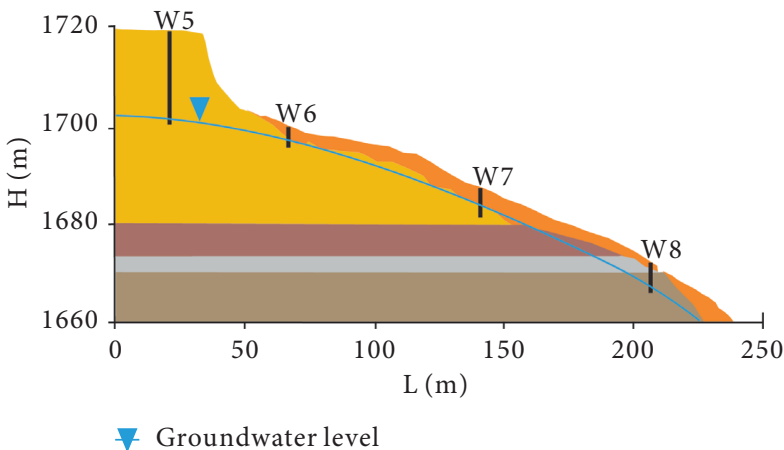

(c)

FIgURE 7: Site monitoring results in Luojiapo (see Figure 4 for actual site locations): (a) changes of soil moisture after irrigation and natural precipitation events; (b) groundwater table changes; and (c) groundwater level at the edge of the tableland.

one hand, the farther the distance from the edge of the tableland was, the higher the pore pressure would be. On the other hand, with the increase of depth, pore pressure increased gradually. The loess at the edge of the slope was relatively dry, while the loess at the foot of the slope and in the interior of the tableland was relatively wet. The pore pressure at the concave slope was higher than that at the convex slope. After irrigation (Figure 8(b)), the difference of pore pressure between irrigated and nonirrigated areas was noticeable. The pore pressure inside the slope, especially in the irrigation area, increased as a whole, while at the edge of the slope, the pore pressure remained almost unchanged. The increase in groundwater level in the irrigated area was higher than that in the nonirrigated area. From Figure 9, with the continuous irrigation, the pore pressure in the slope increased gradually, and the closer to the irrigation area, the more obvious the change of water content will be.

3.4. Slope Stability. Figure 10 shows the results of slope stability analysis before and after irrigation. During the three years' flooding, the slope stability coefficient decreased from 1.10 to 0.98 , and the slope has changed from a stable state to an unstable state. Before irrigation (Figure 10(a)), the maximum shear strain deformation zone was located at the foot of the slope. The maximum shear strain zone extended from the gullies on both sides to the back of the slope, forming a dustpan-shaped potential sliding zone. While after the irrigation (Figure 10(b)), the maximum shear strain area was still at the foot of the slope, but the potential slip zone was a little larger. Compared with Figure 9, it can be seen that the location of deformation and failure was related to the change of pore pressure caused by irrigation, which shows that irrigation not only affected the stability of the slope but also affected the location of the potential sliding zone.

\section{Discussion}

4.1. The Effect of Irrigation on Loess Moisture Content and Groundwater Level. The monitoring results indicated that the effect of irrigation on soil moisture content was more than 3 meters (Figure 7(a)). Zeng et al. [16] also reported that the depth of infiltration into the thick unsaturated loess was not more than $5 \mathrm{~m}$, based on their 2D ERT (electrical resistance tomography) imaging results. Although the moisture content of the loess under 5 meters increased little during irrigation, it increased compared with that before irrigation (Figure 9). Water infiltration simulation by Hou et al. [14] proved the same result. Also, the cracks widely distributed on the tableland edge had a significant effect on the inflow of irrigation water and deep soil moisture [15]. In 

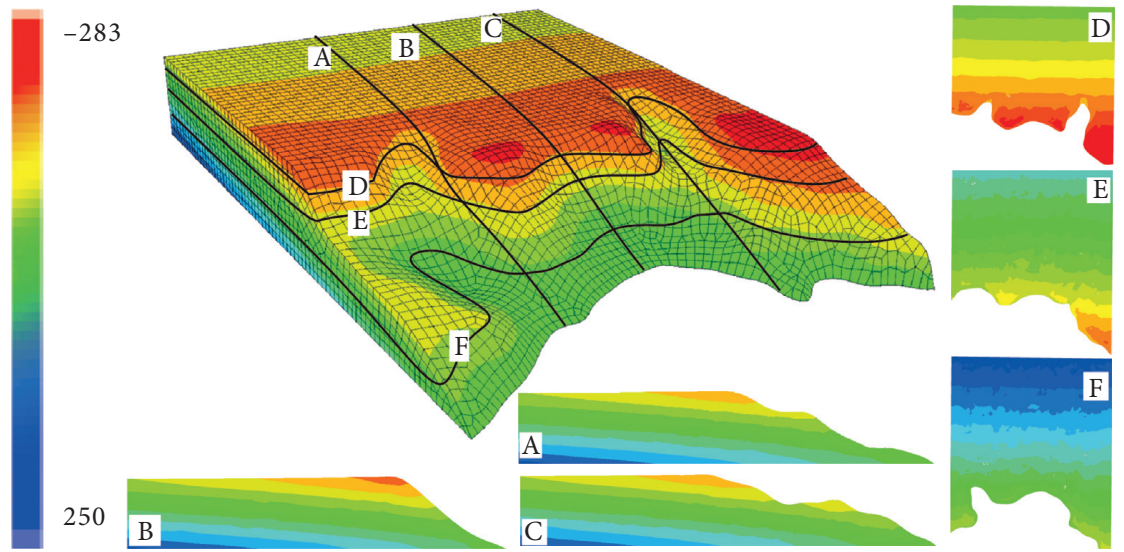

(a)
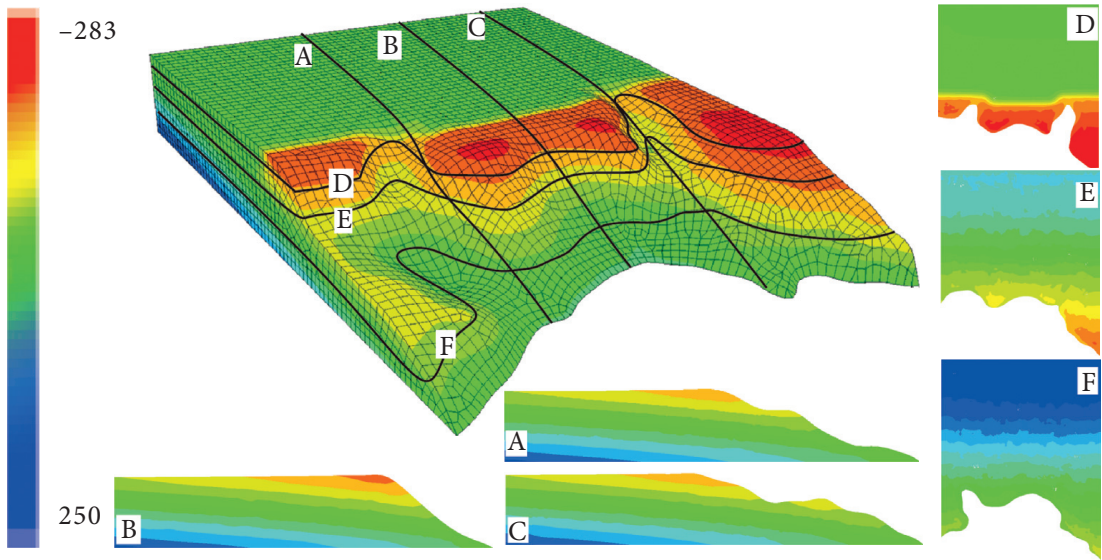

(b)

Figure 8: Pore pressure distribution of the loess layer before (a) and after (b) irrigation (unit of the color legend: $\mathrm{kPa}$; A-F are profile positions).

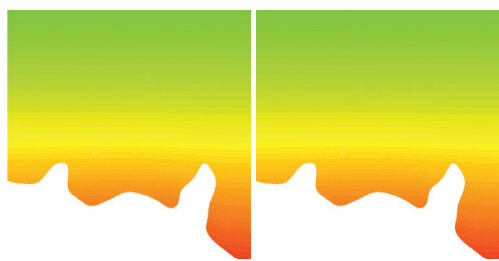

(a)

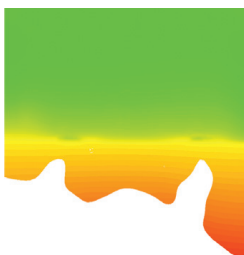

(g) (b)

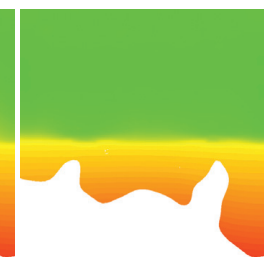

(h)

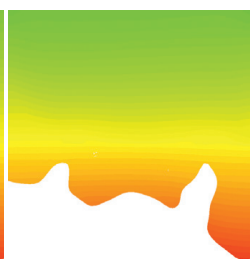

(c)

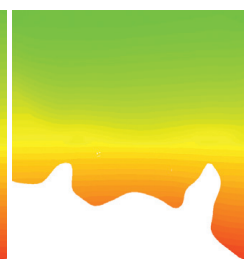

(d)

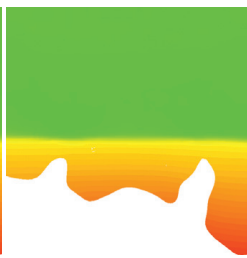

(i)

(j)

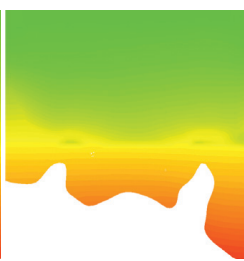

(e)
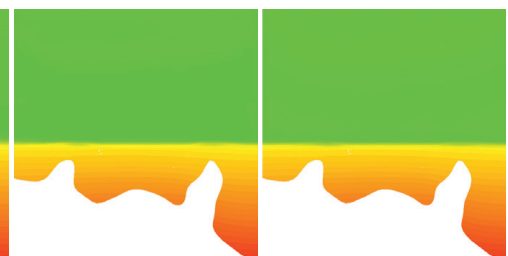

(k)

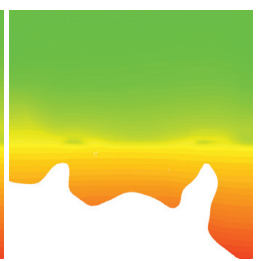

(f)

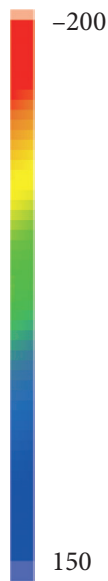

(1)

Figure 9: Pore pressure distribution in slopes (see profile $\mathrm{d}$ in Figure 8 for actual location) of different irrigation stages in days after irrigation unit for the color legend: kPa). (a) $t=0 \mathrm{~d}$, (b) $t=90 \mathrm{~d}$, (c) $t=180 \mathrm{~d}$, (d) $t=270 \mathrm{~d}$, (e) $t=360 \mathrm{~d}$, (f) $t=450 \mathrm{~d}$, (g) $t=540 \mathrm{~d}$, (h) $t=630 \mathrm{~d}$, (i) $t=720 \mathrm{~d},(\mathrm{j}) t=810 \mathrm{~d}$, (k) $t=900 \mathrm{~d}$, and (l) $t=990 \mathrm{~d}$.

general, the moisture content of shallow soil increases sharply, and that of deep soil rises gradually when irrigation. The farther the distance from the edge of the tableland is, the higher the negative pore pressure (matric suction) will be. The pore pressure at the concave slope was higher than that at the convex slope. 


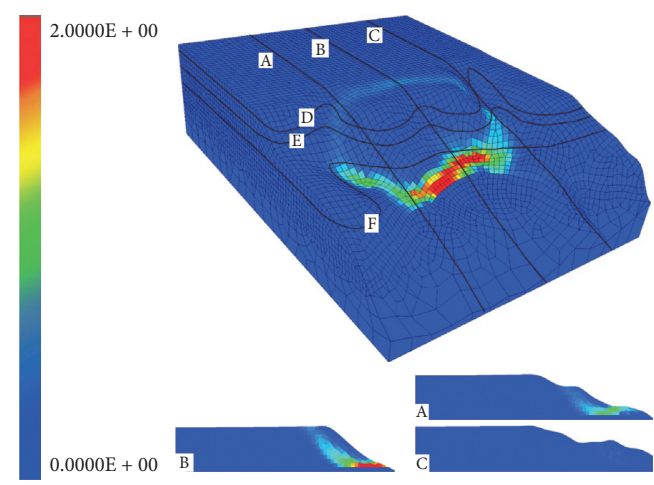

(a)

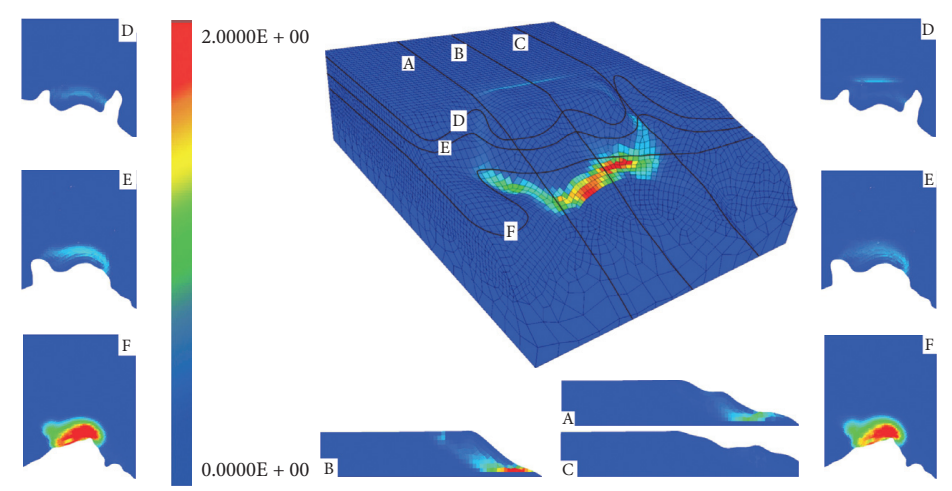

(b)

Figure 10: Maximum shear strain increment of loess slope before (a) and after (b) irrigation (A-F are profile positions).

The monitoring result showed that the annual average rising rate of the groundwater level was about $0.25 \mathrm{~m} / \mathrm{yr}$, which was consistent with the findings of many other scholars $[19,20,36]$. Besides, the groundwater level fluctuated periodically (Figure 11). On the one hand, this was partly due to the lag effect of irrigation on the groundwater level, which could reach as long as five months. Most of the flooding irrigation had been concentrated from mid-March to late November, while there had been little rainfall and irrigation from December to March. The groundwater level rose from August to March of the second year (Figure 7(b)) and decreased from April to July. On the other hand, the freezing action led to the rise of the groundwater level at the edge of the slope. In general, freezing began in late November and thawed in late February of the second year, with the perennial average maximum freezing depth of $0.92 \mathrm{~m}$ [19]. During the cold period, the outlet at the bottom of the slope was frozen, and the pore water pressure at the slope would increase slightly $[40,41]$.

4.2. Change of Loess Strength Caused by Irrigation. According to our laboratory test results, the shear strength of the loess decreased with increasing soil moisture. The strength of the sample with $8.9 \%$ soil moisture (matric suction $200 \mathrm{kPa}$ ) was 1.3 to 1.9 times higher than that of the sample with $39 \%$ soil moisture (matric suction $0 \mathrm{kPa}$ ). The tensile strength decreased exponentially with the increasing soil moisture, and the tensile strength was about $15 \%$ of the cohesion of the loess. However, this was opposite to the change regularity of the strength of frozen loess. The cohesion of frozen loess with a saturation of $90 \%$ was about seven times as much as that at $20 \%$ saturation and ten times as much as that of the original loess with $90 \%$ saturation[45]. It suggested that irrigation can decrease the slope stability by increasing soil moisture of loess in slip zone while seasonal freezing and thawing cycle can slightly increase or decrease the stability by periodic changes in shear strength of surface soil, especially the loess near the foot of the slope.

4.3. Irrigation and Slope Stability. Numerical results showed that the slope stability decreased by 0.1 when the groundwater level rises by $5 \mathrm{~m}$ [21]. According to the current rising rate, the groundwater level would increase by $5 \mathrm{~m}$ in 15 to 20 years. Therefore, the rise of the groundwater level influenced slopes stability in a slow process. Despite this, most slopes in Heifangtai were in or near the limit equilibrium state. The reason was that the groundwater level had risen by more than 20 meters.

Continuous flood irrigation at the back of the slope can accelerate the formation of landslides. The landslides in the Luojiapo section were related to long-term irrigation at the back of the slope (Figures 1(c) and 11), according to field investigation and mapping [5]. As the landform of the landslide is measured by an unmanned aerial vehicle and the landform is obtained by geological drilling, the model is completely consistent with the reality, and the analysis results can explain the actual situation on the site. From 3.4, the slope stability factor has decreased by 0.12 after three consecutive years of irrigation. The slope stability almost decreases linearly when the distance between flood irrigation and the edge of the loess tableland is $>60 \mathrm{~m}$ [33].

The location of landslides was often guided by local topography (Figures 1(c), 3, and 11). On the one hand, landslides, soil erosion, and fluvial erosion resulted in shattered tableland edge. The more concave to tableland is, the shallower the groundwater level will be (Figures 3, 7 and $8 ;[45,46])$, and the more possible landslides will occur. On the other hand, the concave slopes were more susceptible to irrigation, for being close to the farmland (Figures 1(c) and 11; [33]). Therefore, under the effect of irrigation, landslides often occur in the back of the gully or the landslide.

Landslides most frequently occurred in March, followed by July and the least in December (Figure 2(b)). March-June was the time in high demand irrigation, and rainfalls mainly occurred in July. Because of the effect of rainfall infiltration and irrigation, the number of landslides was increased. On the other hand, the stagnation effect led to the rise of the groundwater level at the edge of the slope. The rise of the groundwater level can cause the increase of pore pressure (the decrease of matric suction) and the decrease of shear strength of loess, resulting in the decline of stability and accelerating the process of slope instability. However, during the cold period, the strength of the frozen layer increased, especially the loess at the foot of the slope, where the 

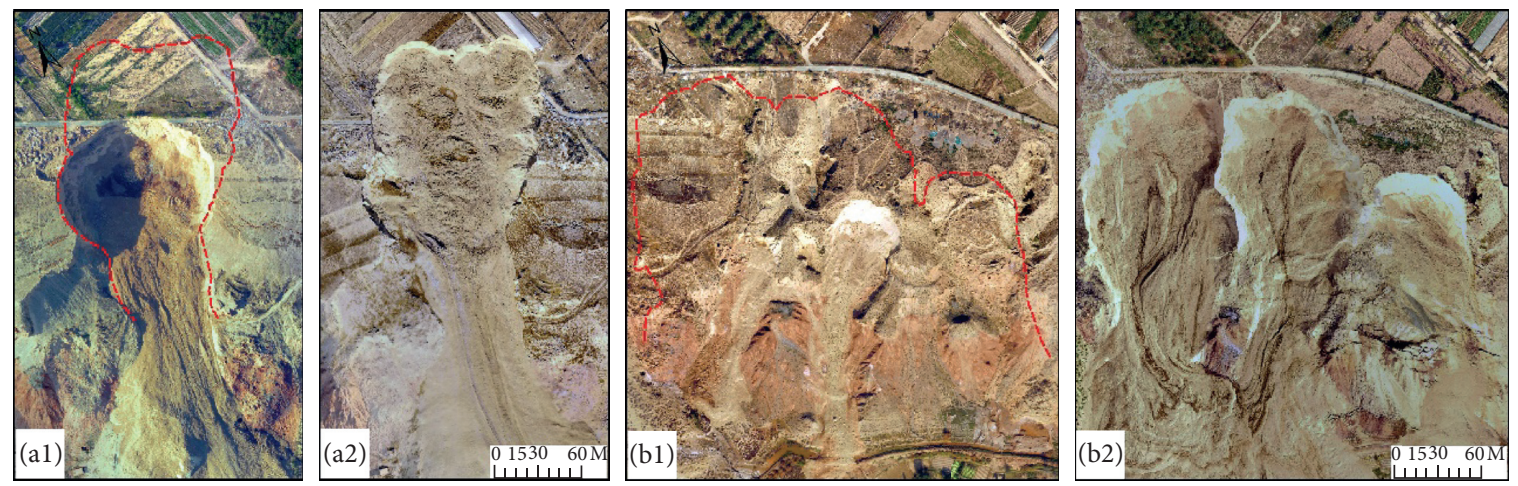

FIGURE 11: Digital orthophoto map of Dangchuan landslide before and after sliding based on UAV photogrammetry. a1: acquisition on November 7, 2016; a2: acquisition on February 28, 2017, sliding on February 19, 2017; b1: acquisition on February 28, 2017; and b2: acquisition on October 11, 2017, sliding on October 1, 2017. Red dashed outlines indicate the extent of the landslides.

groundwater was discharged, and the loess was saturated or nearly saturated. Although the thickness of the frozen layer was less than $1 \mathrm{~m}$, this effect can cause a small increase in stability. At the end of the cold period, the strength of the frozen layer decreased rapidly, while the permeability of loess was limited, and the pore pressure caused by water retention has not dissipated. Under the combined action of these factors, the stability of the slope decreased rapidly, which was also the reason for the high incidence of landslides in spring. This result is consistent with other scholars' studies [46-49].

\section{Conclusions}

The main findings of this study are summarized as follows:

(1) Flood irrigation changed the distribution of soil moisture in the slope. The soil moisture content within 3 meters increased significantly with irrigation. Pore pressure distribution was different in different parts of the slope. The farther the distance from the edge of the tableland was, the higher the negative pore pressure (matric suction) would be. The pore pressure at the concave slope was larger than that at the convex slope. After irrigation, the pore pressure inside the slope, especially in the irrigation area, increased as a whole, while at the edge of the slope, the pore pressure remained almost unchanged.

(2) Long-term irrigation has led to a significant rise in groundwater levels. Monitoring results showed that the rising speed of the groundwater level is about $0.25 \mathrm{~m} / \mathrm{yr}$, with the amplitude being about $0.5 \mathrm{~m}$. The lag effect of irrigation water infiltration on the groundwater level is about five months. Numerical simulation results showed that irrigation raised the water table, and the increase of soil moisture in the flooded area was more significant than that in the nonirrigated area.

(3) After three years of continuous flood irrigation at the back of the slope, the slope stability coefficient decreased by 0.12 , which accelerated the formation of the landslide. Irrigation not only affected the stability of the slope but also affected the location of the potential sliding zone. After irrigation, the potential slip zone was a little larger. The location of deformation and failure was related to the change of pore pressure caused by irrigation. Under the action of flooding, landslides often occurred at the back of the gully or the landslide. The reason was that the water table was shallower on concave slopes and $t$ soil moisture of the concave slopes was more susceptible to irrigation.

\section{Data Availability}

The data used to support the findings of this study were supplied by Jiading Wang under license and so cannot be made freely available. Requests for access to these data should be made to Jiading Wang, wangjiading029@163.com.

\section{Conflicts of Interest}

The authors declare that there are no conflicts of interest regarding the publication of this paper.

\section{Acknowledgments}

This work was supported by the National Natural Science Foundation of China (Grant nos. 41772285, 41630639, and 41530640), National Key Research and Development Plan (2018YFC1504703), and State Key Laboratory of Continental Dynamics. Professor Lin Hangsheng, the coauthor, died of illness. However, he made great contributions to the design of this paper and the revision of the language before his death. The authors cherish the memory of Professor Lin's academic and personal experience.

\section{References}

[1] T.-f. Gu, M.-s. Zhang, J.-d. Wang, C.-x. Wang, Y.-j. Xu, and $\mathrm{X}$. Wang, "The effect of irrigation on slope stability in the Heifangtai Platform, Gansu Province, China," Engineering Geology, vol. 248, pp. 346-356, 2019. 
[2] E. Derbyshire, "Geological hazards in loess terrain, with particular reference to the loess regions of China," EarthScience Reviews, vol. 54, no. 1-3, pp. 231-260, 2001.

[3] P. Guo, X. Meng, Y. Li, G. Chen, R. Zeng, and L. Qiao, "Effect of large dams and irrigation in the upper reaches of the Yellow River of China, and the geohazards burden," Proceedings of the Geologists' Association, vol. 126, no. 3, pp. 367-376, 2015.

[4] Y. Leng, J. Peng, Q. Wang, Z. Meng, and W. Huang, "A fluidized landslide occurred in the Loess Plateau: a study on loess landslide in South Jingyang tableland," Engineering Geology, vol. 236, pp. 129-136, 2018.

[5] J. Peng, F. Zhang, and G. Wang, "Rapid loess flow slides in Heifangtai terrace, Gansu, China," Quarterly Journal of Engineering Geology and Hydrogeology, vol. 50, no. 2, pp. 106110, 2017.

[6] B.-P. Wen and L. He, "Influence of lixiviation by irrigation water on residual shear strength of weathered red mudstone in Northwest China: implication for its role in landslides' reactivation," Engineering Geology, vol. 151, pp. 56-63, 2012.

[7] L. Xu, F. C. Dai, X. B. Tu et al., "Occurrence of landsliding on slopes where flowsliding had previously occurred: an investigation in a loess platform, North-west China," Catena, vol. 104, pp. 195-209, 2013.

[8] F. Zhang and G. Wang, "Effect of irrigation-induced densification on the post-failure behavior of loess flowslides occurring on the Heifangtai area, Gansu, China," Engineering Geology, vol. 236, pp. 111-118, 2018.

[9] J. D. Wang and Y. H. Hui, "Systems analysis on Heifangtai loess landslides in crows induced by irrigated water," Bulletin of Soil and Water Conservation, vol. 21, no. 3, pp. 10-13, 2001.

[10] J. Peng, S. Wang, Q. Wang et al., "Distribution and genetic types of loess landslides in China," Journal of Asian Earth Sciences, vol. 170, pp. 329-350, 2019.

[11] D. Zhang, G. Wang, C. Luo, J. Chen, and Y. Zhou, “A rapid loess flowslide triggered by irrigation in China," Landslides, vol. 6, no. 1, pp. 55-60, 2009.

[12] M. S. Zhang and T. L. Li, "Triggering factors and forming mechanism of loess landslides," Journal of Engineering Geology, vol. 19, no. 4, pp. 530-540, 2011.

[13] I. Hopkins, H. Gall, and H. Lin, "Natural and anthropogenic controls on the frequency of preferential flow occurrence in a wastewater spray irrigation field," Agricultural Water Management, vol. 178, pp. 248-257, 2016.

[14] X. Hou, S. K. Vanapalli, and T. Li, "Water infiltration characteristics in loess associated with irrigation activities and its influence on the slope stability in Heifangtai loess highland, China," Engineering Geology, vol. 234, pp. 27-37, 2018.

[15] L. Xu, F. C. Dai, L. G. Tham et al., "Field testing of irrigation effects on the stability of a cliff edge in loess, North-west China," Engineering Geology, vol. 120, no. 1-4, pp. 10-17, 2011.

[16] R. Q. Zeng, X. M. Meng, F. Y. Zhang et al., "Characterizing hydrological processes on loess slopes using electrical resistivity tomography - a case study of the Heifangtai Terrace, Northwest China," Journal of Hydrology, vol. 541, pp. 742753, 2016.

[17] J. D. Wang, S. F. Xiao, and Z. Y. Zhang, "The mechanism for moving of irrigation-induced high-speed loess landslide," Journal of Engineering Geology, vol. 9, no. 3, pp. 241-246, 2001.

[18] T. Li, P. Li, and H. Wang, "Forming mechanism of landslides in the seasonal frozen loess region in China," Landslides in Cold Regions in the Context of Climate Change, pp. 41-51, 2014.

[19] M. S. Zhang, X. J. Cheng, Y. Dong, G. Q. Yu, L. F. Zhu, and Y. Pei, "The effect of frozen stagnant water and its impact on slope stability: a case study of Heifangtai, Gansu Province," Geological Bulletin of China, vol. 32, no. 6, pp. 852-860, 2013.

[20] F. Zhou, Q. Xu, Y. Z. Ju, D. L. Peng, and X. Qi, "A study of the deformation and failure mechanism of the Heifangtai loess slope," Hydrogeology and Engineering Geology, vol. 44, no. 1, pp. 157-163, 2017.

[21] L. F. Zhu, T. F. Gu, W. Hu, Y. M. Liu, L. Feng, and Y. Q. Bi, "Developmental mechanism of irrigation-induced loess landslides," Journal of Engineering Geology, vol. 24, no. 4, pp. 485-491, 2016.

[22] C. Chen, D. Zhang, and J. Zhang, "Influence of stress and water content on air permeability of intact loess," Canadian Geotechnical Journal, vol. 54, no. 9, pp. 1221-1230, 2017.

[23] K.-H. Yang, T. S. Nguyen, H. Rahardjo, and D.-G. Lin, "Deformation characteristics of unstable shallow slopes triggered by rainfall infiltration," Bulletin of Engineering Geology and the Environment, 2020.

[24] L. Montrasio, R. Valentino, and Q. Chiara, "Estimation of the degree of saturation of shallow soils from satellite observations to model soil slips occurred in emilia romagna region of northern Italy," International Journal of Geosciences, vol. 1, no. 2, pp. 58-65, 2010.

[25] V. R. C. Irene, D. H. Pablo, H. M. V. Manuel, and F. M. Sócrates, "Deep-seated gravitational slope deformations triggered by extreme rainfall and agricultural practices (eastern Michoacan, Mexico)," Landslides, vol. 15, pp. 18671879, 2018.

[26] P. R. Cummins, "Irrigation and the palu landslides," Nature Geoscience, vol. 12, no. 11, pp. 881-882, 2019.

[27] J. Ying, H. J. Liao, and J. H. Yin, “An experimental study on the shear strength of undisturbed loess," ASCE-geotechnical Special Publication, vol. 192, pp. 127-135, 2006.

[28] M. Ueno, T. Nishimura, M. Kato, H. Nakamura, and Z. Si-wei, "Variation of shearing characteristics of loess soil after irrigation," Northwestern Seismological Journal, vol. 27, no. 2, pp. 128-134, 2005.

[29] X. L. Xing, T. L. Li, and Y. K. Fu, "Determination of the related strength parameters of unsaturated loess with conventional triaxial test," Environmental Earth Sciences, vol. 75, no. 1, pp. 82-93, 2016.

[30] L. Xu, M. R. Coop, M. Zhang, and G. Wang, "The mechanics of a saturated silty loess and implications for landslides," Engineering Geology, vol. 236, pp. 29-42, 2018.

[31] Q. Y. Guo, T. F. Gu, and Y. Z. Wu, "A test study of shear strength of unsaturated loess in Yongjing County," Hydrogeology and Engineering Geology, vol. 42, no. 6, pp. 103-107, 2015.

[32] B. Lian, X. Wang, R. Zhu, J. Liu, and Y. Wang, "“A numerical simulation study of landslides induced by irrigation in Heifangtai loess area-a case study of Huangci," IOP Conference Series Earth and Environmental Science, vol. 108, no. 3, pp. 32-64, 2018.

[33] T. F. Gu, M. F. Zhang, J. D. Wang, C. X. Wang, Y. J. Xu, and $\mathrm{X}$. Wang, "Slope edge irrigation and slope stability: Heifangtai platform, Gansu province, China," Engineering Geology, vol. 248, no. 8, pp. 346-356, 2018.

[34] P. Li, X. Zhang, and H. Shi, "Investigation for the initiation of a loess landslide based on the unsaturated permeability and strength theory," Geoenvironmental Disasters, vol. 2, no. 1, pp. 24-35, 2015.

[35] N. Lu, B. Şener-Kaya, A. Wayllace, and J. W. Godt, "Analysis of rainfall-induced slope instability using a field of local factor of safety," Water Resources Research, vol. 48, no. 9, pp. 1-14, 2012. 
[36] P. P. Sun, M. S. Zhang, Y. Dong, G. Q. Yu, and L. F. Zhu, "The coupled analysis of phreatic water flow and slope stability at Heifangtai terrace, Gansu Province," Geological Bulletin of China, vol. 32, no. 6, pp. 887-892, 2013.

[37] W. J. Wu, W. L. Ye, Z. X. Yao, T. Yang, W. H. Wei, and W. Liu, "Characteristics of the Luojiapo loess landslides at Heifangtai, burst on April 29, 2015, in yongjing county, Gansu province," Journal of Glaciology and Geocryology, vol. 38, no. 3, pp. 662-670, 2016.

[38] N. Lu, A. Wayllace, and S. Oh, "Infiltration-induced seasonally reactivated instability of a highway embankment near the Eisenhower Tunnel, Colorado, USA," Engineering Geology, vol. 162, pp. 22-32, 2013.

[39] A. Wayllace and N. Lu, "A transient water release and imbibitions method for rapidly measuring wetting and drying soil water retention and hydraulic conductivity functions," Geotechnical Testing Journal, vol. 35, no. 1, pp. 103-117, 2012.

[40] A. A. Heshmati and M. R. Motahari, "Modeling the dependency of Suction Stress Characteristic Curve on void ratio in unsaturated soils," KSCE Journal of Civil Engineering, vol. 19, no. 1, pp. 91-97, 2015.

[41] Q. Zhai and H. Rahardjo, "Quantification of uncertainties in soil-water characteristic curve associated with fitting parameters," Engineering Geology, vol. 163, pp. 144-152, 2013.

[42] D. G. Fredlund and H. Rahardjo, Soil Mechanics for Unsaturated Soils, Wiley, USA, 1993.

[43] Q. Xu, K. Y. Zhao, F. Z. Zhou, D. L. Peng, and W. L. Chen, "Effects of land use on groundwater recharge of a loess terrace under long-term irrigation," Science of The Total Environment, vol. 751, p. 142340.

[44] T. F. Gu, L. F. Zhu, W. Hu, J. D. Wang, and Y. M. Liu, "Effect on slope stability due to groundwater rising caused by irrigation: a case study of Heifang Platform in Gansu, China," Geoscience, vol. 29, no. 2, pp. 408-413, 2015.

[45] X. J. Cheng, M. S. Zhang, L. F. Zhu, Y. Pei, Z. G. Li, and W. Hu, "Seasonal freeze-thaw action and its effect on the slope soil strength in Heifangtai area," Gansu Province," Geological Bulletin of China, vol. 32, no. 6, pp. 904-909, 2013.

[46] F. Zhang, G. Wang, T. Kamai, W. Chen, D. Zhang, and J. Yang, "Undrained shear behavior of loess saturated with different concentrations of sodium chloride solution," Engineering Geology, vol. 155, pp. 69-79, 2013.

[47] S. H. Kværnø and L. Øygarden, "The influence of freeze-thaw cycles and soil moisture on aggregate stability of three soils in Norway," Catena, vol. 67, no. 3, pp. 175-182, 2006.

[48] J. Yi, Y. Zhao, M. a. Shao, J. Zhang, L. Cui, and B. Si, "Soil freezing and thawing processes affected by the different landscapes in the middle reaches of Heihe River Basin, Gansu, China," Journal of Hydrology, vol. 519, pp. 1328-1338, 2014.

[49] D. Peng, Q. Xu, F. Liu et al., "Distribution and failure modes of the landslides in heitai terrace, China," Engineering $\mathrm{Ge}$ ology, vol. 236, pp. 97-110, 2018. 